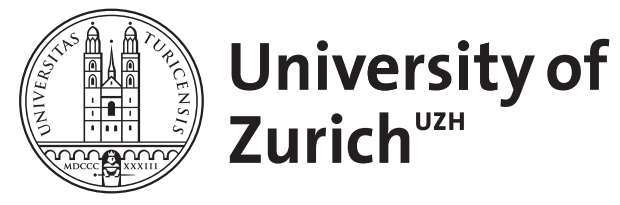

Essential oils of aromatic plants with antibacterial, antifungal, antiviral, and cytotoxic properties - an overview

Reichling, J ; Schnitzler, P ; Suschke, U ; Saller, R

DOI: https://doi.org/10.1159/000207196

Posted at the Zurich Open Repository and Archive, University of Zurich ZORA URL: https://doi.org/10.5167/uzh-18705

Journal Article

Published Version

Originally published at:

Reichling, J; Schnitzler, P; Suschke, U; Saller, R (2009). Essential oils of aromatic plants with antibacterial, antifungal, antiviral, and cytotoxic properties - an overview. Forschende Komplementärmedizin, 16(2):79-90.

DOI: https://doi.org/10.1159/000207196 


\title{
Essential Oils of Aromatic Plants with Antibacterial, Antifungal, Antiviral, and Cytotoxic Properties - an Overview
}

\author{
Jürgen Reichling ${ }^{\mathrm{a}} \quad$ Paul Schnitzler $^{\mathrm{b}} \quad$ Ulrike Suschke $^{\mathrm{a}} \quad$ Reinhard Saller $^{\mathrm{c}}$ \\ ${ }^{a}$ Institute of Pharmacy and Molecular Biotechnology, Department of Biology, \\ ${ }^{\mathrm{b}}$ Hygiene Institute, Department of Virology, University of Heidelberg, Germany \\ ${ }^{c}$ Institute of Complementary Medicine, Department of Internal Medicine, University Hospital Zurich, Switzerland
}

\author{
Key Words \\ Essential oils - Medicinal plants - Antimicrobial effects . \\ Cytotoxic properties
}

\section{Summary}

The abundant use of anti-infective agents resulted in the emergence of drug-resistant bacteria, fungi, and viruses. To overcome the increasing resistance of pathogenic microbes, a variety of medicinal plants have been screened worldwide for their antimicrobial properties. The aim is to find new, effective antimicrobial agents with novel modes of actions. Essential oils derived from aromatic medicinal plants have been reported to exhibit exceptionally good antimicrobial effects against bacteria, yeasts, filamentous fungi, and viruses. The progress of this expanding scientific field will be documented by the most important results published in the last decade.

\section{Introduction}

The indiscriminate use of antimicrobial agents has resulted in the emergence of a number of drug-resistant bacteria, fungi, and viruses. To overcome the increasing resistance of pathogenic microbes, more effective antimicrobial agents with novel modes of action must be developed. Medicinal plants used in traditional medicines to treat infectious diseases seem to be an abundant source of new bioactive secondary metabolites. Therefore, in the last few years, a variety of medicinal plants and plant extracts have been screened for their antimicrobial activity $[1,2]$. Essential oils, derived from aromatic medicinal

\section{KARGER}

Fax +497614520714

Information@Karger.de

www.karger.com (c) 2009 S. Karger GmbH, Freiburg

Accessible online at:

www.karger.com/fok

\section{Schlüsselwörter}

Ätherische Öle · Arzneipflanzen · Antimikrobielle Aktivität . Zytotoxische Eigenschaften

\section{Zusammenfassung}

Der übermäßige Gebrauch von Antiinfektiva führte zum Auftreten von resistenten Bakterien, Pilzen und Viren. Um die vermehrte Resistenz von Mikroben zu überwinden, sind weltweit verschiedene Arzneipflanzen auf ihre antimikrobiellen Eigenschaften untersucht worden. Das Ziel ist es, neue, wirksame Antiinfektiva mit neuartigen Wirkmechanismen zu finden. Ätherische Öle bestimmter Arzneipflanzen sind dafür bekannt, dass sie eine besonders gute Wirkung gegen Bakterien, Pilze und Viren aufweisen. Der Fortschritt auf diesem wachsenden Forschungsgebiet soll durch die wichtigsten Ergebnisse, die im letzten Jahrzehnt publiziert worden sind, dokumentiert werden. plants (e.g. fennel (Foeniculum vulgare), peppermint (Mentha piperita), thyme (Thymus vulgaris)), have been reported to be active against Gram-positive and Gram-negative bacteria as well as against yeasts, fungi, and viruses. They are mixtures of different lipophilic and volatile substances, such as monoterpenes, sesquiterpenes, and/or phenylpropanoids, and have a pleasant odor. Furthermore, they are considered to be part of the preformed defense system of higher plants [3].

Whilst it is beyond the scope of the present survey to review this expanding scientific field extensively, its progress will be documented by the most important results published in the last decade. 
Table 1. A selection of aromatic plants with antimicrobial active essential oils

\begin{tabular}{|c|c|c|c|c|c|c|}
\hline Origin of essential oil & Bacteria Gram (+) & Bacteria Gram (-) & Yeasts, y & Fungi, $f$ & $\mathrm{MIC}, \mu \mathrm{g} / \mathrm{ml}$ & References \\
\hline Allium sativum & & & $\mathrm{y}$ & $\mathrm{f}$ & 64.0 & {$[4]$} \\
\hline Artemisia douglasiana & + & - & $\mathrm{y}$ & & $156-625$ & {$[5]$} \\
\hline Commiphora mukul & + & - & & & $0.31-5 \%$ of oil & {$[6]$} \\
\hline Cryptomeria japonica & & & $\mathrm{y}$ & $\mathrm{f}$ & EC50: 39-110 & [7] \\
\hline Foeniculum vulgare & + & - & & & $0.25-2.0 \%$ of oil & {$[8]$} \\
\hline Juniperus communis & + & - & & & $1.0-2.0 \%$ of oil & [8] \\
\hline Lavandula angustifolia & & & $\mathrm{y}$ & & $0.69-1.8 \%$ of oil & {$[9]$} \\
\hline Melaleuca alternifolia & & & $\mathrm{y}$ & & $0.03-0.125$ & {$[10]$} \\
\hline Mentha arvensis & + & - & & $\mathrm{f}$ & $400-800$ & {$[11]$} \\
\hline Mentha spicata & + & - & & & $400-800$ & {$[11]$} \\
\hline Nigella sativa & + & & $\mathrm{y}$ & $\mathrm{f}$ & 2500 & {$[12]$} \\
\hline Peumus boldus & + & - & $\mathrm{y}$ & & $0.9-58.0$ & {$[13]$} \\
\hline Pimpinella anisum & & & $\mathrm{y}$ & $\mathrm{f}$ & $0.78-1.56 \%$ of oil & {$[14]$} \\
\hline Salvia sclarea & & & & $\mathrm{f}$ & EC50: 493-584 $\mu \mathrm{l} / 1$ & {$[15]$} \\
\hline Tagetes patula & & & $\mathrm{y}$ & $\mathrm{f}$ & $1.25-10.0 \mu \mathrm{l} / \mathrm{ml}$ & {$[16]$} \\
\hline Thymbra capitata & & & $\mathrm{y}$ & $\mathrm{f}$ & $0.08-0.32 \mu \mathrm{l} / \mathrm{ml}$ & {$[17]$} \\
\hline Thymus pulegioides & & & $\mathrm{y}$ & $\mathrm{f}$ & $0.16-0.64 \mu \mathrm{l} / \mathrm{ml}$ & [18] \\
\hline Ziziphora clinopodioides & + & - & & & 3,750 & [19] \\
\hline
\end{tabular}

MIC = Minimum inhibitory concentration; $\operatorname{Gram}(+)=$ Gram-positive; Gram $(-)=$ Gram-negative; EC $\mathrm{C}_{50}=$ effective concentration of the test compound which inhibit the growth of fungus by $50 \%$.

\section{Medicinal Plants with Antibacterial and Antifungal Essential Oils}

During the last decade, a variety of essential oils have been screened to assess their antimicrobial activity (table 1). The antimicrobial activity of plant-derived essential oils formed the basis of many applications, especially in food preservation, aromatherapy, and complementary medicine.

\section{Essential Oils with Anti-Helicobacter Activity}

Helicobacter pylori is a Gram-negative bacterium that colonizes the epithelial surface of gastric mucosa. Nowadays, there is no doubt that $H$. pylori is a major etiological agent of acute and chronic gastritis. The role of the bacterium in the pathogenesis of peptic ulcer as well as in the development of adenocarcinoma of the distal stomach has been well-established. To cure a H. pylori infection, a combined treatment of proton pump inhibitor with two antibiotics has shown to be successful. Since antibiotic resistance has developed, it is also necessary to find new agents against this type of bacterium as alternatives to existent antibiotics or as adjuvant agents in combination with established and still effective antibiotics.

Recently, isolated plant substances (e.g. alkaloids, flavonoids, polysaccharides) as well as plant extracts have been shown to be effective against $H$. pylori. In the last decade, several research groups have investigated essential oils from different plant origin for their anti-Helicobacter activity using a broth microdilution/macrodilution method (table 2).

All essential oils tested exhibited a high anti-Helicobacter activity in vitro with $\mathrm{MIC} / \mathrm{MBC}$ values of $20.0-589.4 \mu \mathrm{g} / \mathrm{ml}$. Of all essential oils tested, carrot (Daucus carota) seed oil was the
Table 2. Essential oils with antibacterial activity against Helicobacter pylori (values in italics indicate MBC values)

\begin{tabular}{|c|c|c|}
\hline Origin of essential oil & $\mathrm{MIC} / \mathrm{MBC}, \mu \mathrm{g} / \mathrm{ml}$ & References \\
\hline Daucus carota & 20.0 & {$[20]$} \\
\hline Cinnamomum zeylanicum & 40.0 & {$[20]$} \\
\hline Satureja montana & 40.0 & {$[20]$} \\
\hline Matricaria recutita & $35.7-70.4$ & {$[21]$} \\
\hline Nepeta argolica & 64.0 & {$[22]$} \\
\hline Citrus aurantium & 65.1 & {$[21]$} \\
\hline Mentha spicata & $50.0-100.0$ & {$[11]$} \\
\hline Zingiber officinale & $65.4-130.9$ & {$[21]$} \\
\hline Eugenia caryophyllus & 100.0 & {$[20]$} \\
\hline Mentha arvensis & 100.0 & {$[11]$} \\
\hline Nepeta camphorata & 128.0 & {$[22]$} \\
\hline Melissa officinalis & 135.7 & {$[21]$} \\
\hline Mentha piperita & 135.7 & {$[21]$} \\
\hline Salvia officinalis & 137.6 & {$[21]$} \\
\hline Rosmarinus officinalis & 137.0 & {$[21]$} \\
\hline Leptospermum scoparium & 140.0 & {$[21]$} \\
\hline Elettaria cardamomum & $130.0-278.0$ & {$[21]$} \\
\hline Thymus vulgaris & 275.2 & {$[21]$} \\
\hline Coriandrum sativum & 259.3 & {$[21]$} \\
\hline Foeniculum vulgare & 288.3 & {$[21]$} \\
\hline Carum carvi & 273.1 & {$[21]$} \\
\hline Ocimum basilicum & $286.7-573.4$ & {$[21]$} \\
\hline Illicium verum & $294.7-589.4$ & {$[21]$} \\
\hline Melaleuca alternifolia & 539.0 & {$[21]$} \\
\hline
\end{tabular}

$\mathrm{MIC}=$ Minimum inhibitory concentration; $\mathrm{MBC}=$ minimum bactericidal concentration.

most active one with an MBC value of $20.0 \mu \mathrm{g} / \mathrm{ml}$. Moreover, recent studies reported the in vivo (e.g. mice and rats) efficiency of different essential oils against antibiotic-susceptible and 
-resistant H. pylori strains. It was also of interest that the bactericidal activities of the essential oils tested were enhanced at acidic $\mathrm{pH}$ values $[20,23,24]$. Some scientists speculate that the anti-Helicobacter activities of several essential oils are relevant if one intends to use them as food supplement to complement standard therapy [20].

Tea Tree (Melaleuca alternifolia) Oil (TTO) with AntiMycoplasma pneumoniae Activity

Mycoplasmas are bacteria without a rigid cell wall. Their physiological habitats are plants and animals but in various circumstances they may become pathogenic for humans, too. Mycoplasma pneumoniae is spread all over the world. It frequently causes atypical courses of pneumonia, particularly in children between 5 and 15 years and adults between 30 and 35 years. As a result of lung inflammations, myocarditis, arthritis, polyneuritis, and other chronic diseases may appear. Tetracyclines and macrolides are the preferred antibiotics in the treatment of mycoplasmal infections. However, in recent years bacterial strains emerged with a resistance to macrolide antibiotics.

The most common morphological shape of M. pneumoniae is the typical 'pear shape' with a tip structure at one end of the cell. There are specific protein filaments inside the tip structure which form the cytoskeleton [25]. When M. pneumoniae was treated with $0.006 \%$ TTO in ethanol $(1 \%)$ for $12 \mathrm{~h}$, the cells lost their typical 'pear-shaped' appearance and became rounded. The rounded shape resembles mutants which have lost their virulence as a result of this morphological change and the loss of their attachment site. TTO seems to affect the intracellular cytoskeletal structure in a way that M. pneumoniae cells become rounded and lose their virulence. On the other hand, the integrity of the cell membrane was not impaired by TTO [25].

In a recent in vitro experiment, Furneri et al. [26] exposed 25 clinically isolated strains from vagina, urethra, cervix, 1 reference strain of Mycoplasma hominis, 1 clinically isolated strain, 1 reference strain of $M$. pneumoniae, 4 clinically isolated strains (from vagina), and 2 reference strains of $\mathrm{Myco-}$ plasma fermentans to TTO. The MIC values were determined by a broth microdilution assay (table 3 ).

All Mycoplama species tested revealed, independently of their origin, a high susceptibility against TTO in vitro.

\section{Antibacterial Activity against Bacteria from the Respiratory Tract}

Essential oils are traditionally used for the treatment of respiratory tract infections due to their secretolytic and secretomotoric properties. Therefore, essential oils are either inhaled by steam, applied by inunction to the chest, or administered orally.

Bacterial respiratory tract infections develop in many cases from viral infections as common colds and include tonsillitis, sinusitis, bronchitis, and pneumonia. The bacteria most frequently isolated from the respiratory tract are Streptococcus pneumoniae, Haemophilus influenzae, Moraxella catarrhalis, and Streptococcus pyogenes. Therefore, it is of interest to focus

Table 3. Susceptibility of different Mycoplasma species against tea tree (Melaleuca alternifolia) oil

\begin{tabular}{ll}
\hline Bacteria & MIC, \% \\
\hline Mycoplasma hominis (26 isolates) & $0.06-0.12$ \\
Mycoplasma fermentans (6 isolates) & $0.01-0.06$ \\
Mycoplasma pneumoniae (2 isolates) & 0.01 \\
\hline
\end{tabular}

Table 4. Antimicrobial activity of various essential oils against bacteria of the respiratory tract (MIC values in $\mu \mathrm{g} / \mathrm{ml})$

\begin{tabular}{|c|c|c|c|c|c|}
\hline Origin of essential oil & S. pneumoniae & S. pyogenes & H. influenzae & M. catarrhalis & References \\
\hline \multirow[t]{3}{*}{ Thymus vulgaris } & 800 & 200 & 200 & - & {$[27,28]$} \\
\hline & $3.13 *$ & $6.25^{*}$ & $3.13 *$ & - & \\
\hline & 6250 & 12500 & 12500 & - & {$[29]$} \\
\hline \multirow[t]{3}{*}{ Cinnamomum verum } & 400 & 200 & 200 & - & {$[27,28]$} \\
\hline & $3.13^{*}$ & $6.25 *$ & $3.13 *$ & - & {$[27,28]$} \\
\hline & 6250 & 6250 & 6250 & - & {$[29]$} \\
\hline Melissa officinalis & 139 & 557 & 278 & 139 & {$[30,31]$} \\
\hline Nepeta cataria & 332 & 1329 & 664 & 332 & \\
\hline \multirow[t]{2}{*}{ Cymbopogon citratus } & 800 & 400 & 800 & - & {$[27,28]$} \\
\hline & $6.25^{*}$ & $6.25 *$ & $1.56^{*}$ & - & {$[27,28]$} \\
\hline \multirow[t]{2}{*}{ Mentha piperita } & 3200 & 1600 & 800 & - & {$[27,28]$} \\
\hline & $25^{*}$ & $25^{*}$ & $12.5^{*}$ & - & {$[27,28]$} \\
\hline \multirow[t]{2}{*}{ Melaleuca alternifolia } & 3200 & 3200 & 1600 & - & {$[27,28]$} \\
\hline & $25^{*}$ & $50 *$ & $50 *$ & - & {$[27,28]$} \\
\hline \multirow[t]{2}{*}{ Eucalyptus radiata } & 3200 & $>3200$ & - & - & {$[27,28]$} \\
\hline & $25^{*}$ & $50 *$ & $50 *$ & - & {$[27,28]$} \\
\hline Syzygium aromaticum & 12500 & 12500 & 12500 & - & [29] \\
\hline
\end{tabular}




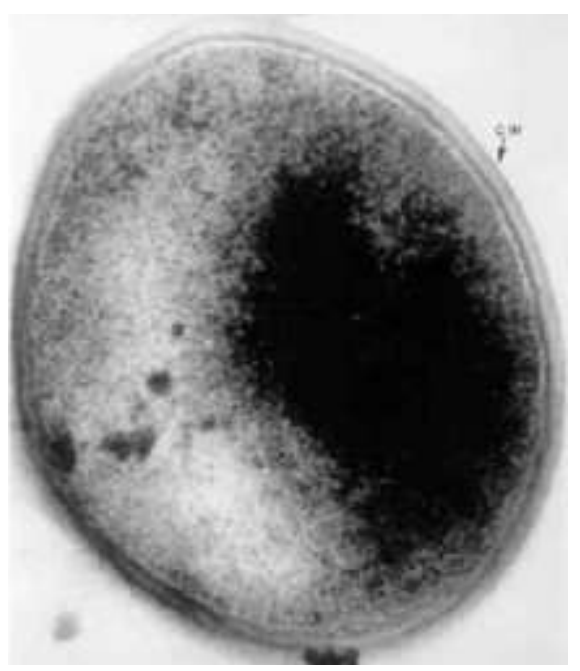

a

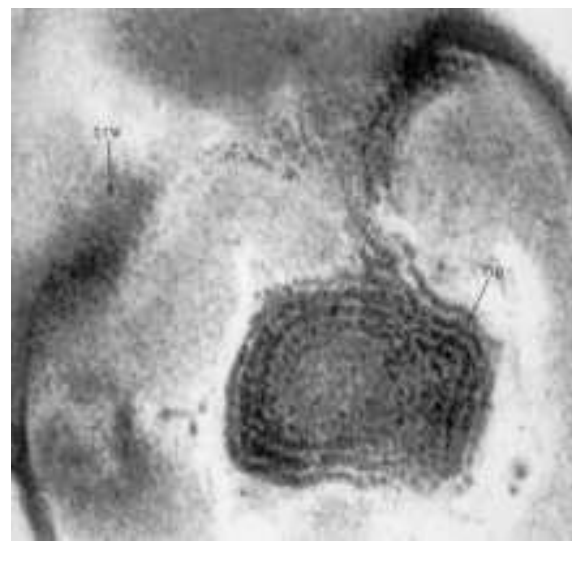

c

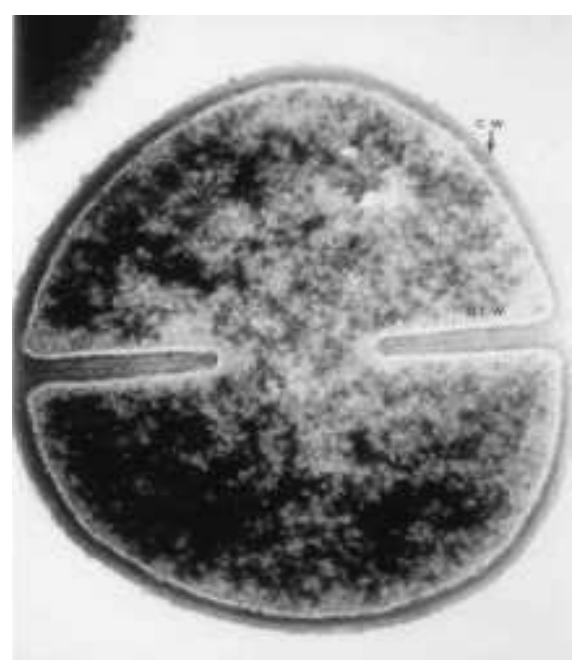

b

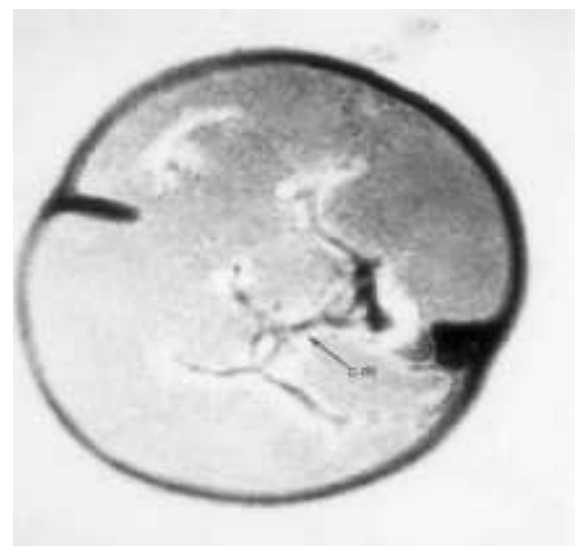

d on the susceptibility of these bacteria to essential oils. Table 4 gives an overview on the MIC values of different oils tested. Especially $S$. pneumoniae, $H$. influenzae, and $M$. catarrhalis were susceptible in vitro to lemon balm (Melissa officinalis) oil, thyme (T. vulgaris) oil, cinnamon bark (Cinnamomum verum) oil, and lemon grass (Cymbopogon citratus) oil. The oils of peppermint (M. piperita) and eucalyptus (Eucalyptus globulus) frequently used for the treatment of colds displayed lower activity. Interestingly, in gaseous phase, concentrations of $1.56-6.25 \mu \mathrm{g} / \mathrm{ml}$ of the most active oils were sufficient to inhibit bacterial growth, so that an antibacterial effect on inhalation might be plausible [27, 28].

Investigations on the antibacterial activity of essential oil components displayed similar results: most active groups of constituents were monoterpene alcohols and aldehydes as well as phenols and cinnamaldehyde with MIC-values of 160-300 $\mu \mathrm{g} / \mathrm{ml}$ to both $S$. pneumoniae and $H$. influenzae [27, 28, 32].

Tee Tree Oil Activity in Staphylococcus aureus Cells an Electron Microscopic Study

Staphylococcus aureus is one of the most important Grampositive bacteria in humans, causing localized or generalized septic infections. Methicillin-resistant strains (MRSA) usually colonize the anterior nares of hospital patients and healthy individuals and cause epidemics in hospitals.

TTO is successfully used worldwide in nursing, in skin care cosmetics, and to treat certain local bacterial and fungal infections [33-35]. TTO could be shown to reveal a high antibacterial activity against $S$. aureus in vitro and in vivo [36, 37]. To learn more about the mode of action, we studied the biological effect of TTO on cell ultrastructures, such as cytoplasm, cytoplasmic membrane, and cell wall using electron microscopy [38].

$S$. aureus belongs to the micrococcus family forming round to oval cells (fig. 1a) which are usually arranged in clusters. Untreated bacteria displayed normally dividing staphylococci cells (fig. 1b) and a sharp delineation between cell wall, cytoplasmic membrane, and the cytoplasm. In addition, cytoplasm revealed an evenly granular distribution. After $12 \mathrm{~h}$ exposure to a subminimum inhibitory concentration (sub-MIC) of $0.12 \%$ TTO, neither cell shape nor cell wall and cytoplasmic membrane revealed any irregularities or alterations. In contrast, cell division of the bacterial cells seemed to be interrupted, and, in the cytoplasm, lamellar-like membrane rods were seen (fig. 1c). The formation of lamellar-like membrane 
Table 5. Cell targets and physiological effects of selected essential oils

\begin{tabular}{|c|c|c|c|}
\hline Targets & Bacteria/Fungi & Substances & References \\
\hline \multicolumn{4}{|l|}{ Cell morphology } \\
\hline $\begin{array}{l}\text { Forming elongated filamentous forms after treatment } \\
\text { with essential oil; normal cells: } 3-5 \mu \mathrm{m} \text { in length; } \\
\text { elongated cells: } 10-25 \mu \mathrm{m} \text { in length }\end{array}$ & E. coli & palmarosa oil; peppermint oil & {$[44]$} \\
\hline $\begin{array}{l}\text { Alteration of cell shape: cells of wild type exhibit } \\
\text { a flask-shaped morphology, whereas TTO-treated } \\
\text { strains form ovoid or round cells. }\end{array}$ & M. pneumoniae & TTO & [25] \\
\hline
\end{tabular}

Cytoplasmic membrane (alteration of integrity and permeability)

Inhibition of cell respiration

E. coli; S. aureus; C. albicans TTO

$[35,40,41]$

Inhibition of oxygen uptake, respiratory electron

R. sphaeroides

flow and oxidative phosphorylation

E. coli. S. aureus

$\mathrm{K}^{+}$leakage

E. coli, L. monocytogenes,

E. coli

Depletion of intracellular ATP concentration

S. aureus

Formation of multilamellar, mesosome-like structures

Candida albicans, C. glabrata, Saccharomyces cerevisiae

thymol, carvacrol and other monot- [45] erpene alcohols

TTO; farnesol, nerolidol

[40, 41, 46, 47]

oregano oil, cinnamon oil, savory oil; carvacrol, thymol

TTO; terpinen-4-ol

TTO; terpinen-4-ol; $\alpha$-terpineol;

1.8-cineol; $\gamma$-terpinene; $\alpha$-terpinene

Changes in membrane fluidity

Candida albicans; C. glabrata;

TTO; 1.8-cineol;

S. cerevisiae

terpinen-4-ol; $\alpha$-terpinene

Lesion of cytoplasmic membrane; reduction of

C. albicans,

Thymus pulegioides oil ergosterol content in the cell membrane

Aspergillus fumigatus

Cell wall

Formation of extracellular blebs

E. coli

TTO; lemongrass oil

Disintegration of outer membrane (OM) and

E. coli

thymol, carvacrol

OM-associated LPS release

S. pneumoniae; E. coli,

oregano oil, thyme oil;

B. subtilis

oregano oil, clove oil

Cell division

Total inhibition of cell division

S. aureus

TTO

Anti-R-plasmid activity

Elimination of R-plasmids

E. coli

peppermint oil, rosemary oil, eucalyptus oil; menthol

Cell cytoplasm/cytosol

Formation of condensed, filamentous,

S. aureus

TTO

electron-dense material in the cytoplasm/cytosol

Bacteria: Bacillus subtilis (B. subtilis), Escherichia coli (E. coli), Staphylococcus aureus (S. aureus), Streptococcus pneumoniae (S. pneumoniae), Rhodopseudomonas sphaeroides (R. sphaeroides), Listeria monocytogenes (L. monocytogenes), Mycoplasma pneumoniae (M. pneumoniae).

Fungi: Candida albicans (C. albicans).

Essential oil: Palmarosa oil: Cymbopogon martini oil; peppermint oil: Mentha piperita oil; TTO: Melaleuca alternifolia oil; oregano oil: Origanum vulgare oil; cinnamon oil: Cinnamomum verum oil; savory oil: Satureja montana oil; lemon grass oil: Cymbopogon citratus oil; clove oil: Syzygium aromaticum oil; rosemary oil: Rosmarinus officinalis oil; eucalyptus oil: Eucalyptus globulus oil.

or so-called mesosome-like membrane structures seems to be an expression of general cell damage. This observation indicates that there is a lasting effect of sub-MIC of $0.12 \%$ TTO on cell physiology.

These findings correspond very well to experiences with antibiotics. Ultrastructural changes in bacterial cells produced by antibiotics at MIC levels differ clearly from those obtained by antibiotics at sub-MIC [39]. After $12 \mathrm{~h}$ of incubation of the bacterial cells with the MIC of $0.25 \%$ TTO, dramatic cellular alterations became visible on electron microscopic image: Cell division was inhibited completely, in cytoplasm a clear segregation of previously distributed cell components was found, 
new fibrous electron-dense structures were seen, and lamellar-like membrane rods were no longer visible (fig. 1d).

Interestingly, there was no shrinkage or busting of bacterial cells in the MIC dose range; furthermore, neither the cell walls nor the cytoplasmic membranes seemed to be destroyed by TTO.

In a similar electron microscopic study, Escherichia coli cells cultivated in the presence of TTO (MIC: 0.25\%) showed a loss of electron-dense material, coagulation of cell cytoplasm as well as the formation of extracellular blebs. In addition, Cox et al. [40, 41] could demonstrate that TTO concentrations that inhibit the growth of $E$. coli and $S$. aureus also inhibited cell respiration, stimulated the leakage of intracellular $\mathrm{K}^{+}$ions, and altered the permeability of the bacterial cytoplasmic membrane.

\section{Mode of Antimicrobial Action}

While essential oils were extensively tested against a broad spectrum of bacteria, yeasts, and fungi, the interaction between essential oils and microbes which ultimately induces the antimicrobial activity is not well understood. Hitherto, different target sites and modes of action are discussed (table 5). Previously, Takaisi-Kikuni et al. [42] studied the effect of various amounts of the essential oil of Cymbopogon densiflorus on the metabolic activity, growth, and morphology of $S$. aureus. Relatively high concentrations of the oil impaired staphylococcal growth in a bacteriostatic manner (chloramphenicol-type), and in low doses metabolism became ineffective due to energy losses in the form of heat. Ultrastructural data revealed morphological changes characteristic of the induction of bacteriolysis by bactericidal antibiotics (penicillin-type). Hammer et al. [34] investigated the antifungal effects of tea tree (M. alternifolia) oil and several of its components on Candida albicans, Candida glabrata, and Saccharomyces cerevisiae. TTO and its components were reported to alter both permeability and membrane fluidity of the yeasts tested. Based on these results, it was assumed that the essential oils may have antimicrobial activity by influencing bacterial and fungal targets involved in cytoplasmatic and cell wall metabolism. It is stated by several researchers that especially monoterpenes will increase cytoplasmic membrane fluidity and permeability, disturb the order of membrane embedded proteins, inhibit cell respiration, and alter ion transport processes [32, 43].

\section{Essential Oils with Antiviral Properties}

Natural products, either as pure compounds or as standardized plant extracts, provide unlimited opportunities for new antiviral drugs, since the chemical diversity provides unmatched availability [55]. Besides small molecules from medicinal chemistry, natural products are still major sources of innovative therapeutic agents for various conditions, including infectious diseases. Infectious viral diseases remain an im- portant worldwide problem, since many viruses have resisted prophylaxis or therapy longer than other microorganisms. At the moment, only few effective antiviral drugs are available for the treatment of viral diseases. There is a need to find new substances with not only intracellular but also extracellular antiviral properties. The methods commonly used for the evaluation of in vitro antiviral activities of synthetic and natural substances are based mainly on the inhibition of cytopathic effects, the reduction or inhibition of plaque formation, and the reduction in the virus yield, but also on other viral functions in selected host cell cultures.

\section{Inhibition Activity against Different Human Viruses}

There is considerable evidence emerging from in vitro studies and controlled trials of the potential of plant-derived phytoantiviral agents for the treatment of human viral infections. Many essential oils were investigated towards their antiviral activity. Most of them were tested against enveloped RNA and DNA viruses, such as herpes simplex virus type 1 and type 2 (DNA viruses), dengue virus type 2 (RNA virus), Junin virus (RNA virus), and influenza virus (RNA virus), whereas only few essential oils, e.g. oregano (Origanum vulgare) oil and clove (Syzygium aromaticum) oil, were also tested against non-enveloped RNA and DNA viruses, such as adenovirus type 3 (DNA virus), poliovirus (RNA virus), and coxsackievirus B1 (RNA virus).

Herpes simplex virus type 1 (HSV-1) causes some of the most common viral infections in humans, such as mucocutaneous herpes infections, herpetic keratitis, herpetic encephalitis, and neonatal herpes. Following primary infection, the particles of HSV-1 are carried by retrograde transport via sensory nerve endings to the ganglia, where the virions remain in a latent state until the development of reactivation by different stimuli. Acyclovir, a nucleoside analogue and selective anti-herpetic agent which has been widely used for therapy, inhibits the viral DNA replication through viral thymidine kinase, resulting in a potent inhibition of viral DNA synthesis. However, acyclovir-resistant herpesviruses have been increasingly isolated, particularly from immunocompromised hosts, such as patients with AIDS or malignancy, and recipients of bone marrow or organ transplantation $[56,57]$.

The antiviral activity of the essential oils tested could be clearly demonstrated for enveloped DNA and RNA viruses (table 6). In contrast, the non-enveloped viruses were not affected by essential oils. A high antiviral effect of several essential oils against acyclovir-resistant clinical isolates of herpes simplex virus has been demonstrated recently [58].

\section{Mode and Mechanism of Antiviral Action}

The best candidates as clinically useful antiviral drugs are substances which act on specific steps of viral biosynthesis. They inhibit specific processes in the viral replication cycle, 
Table 6. Antiviral activity of essential oils against different human viruses

\begin{tabular}{|c|c|c|c|}
\hline Origin of essential oil & Virus & $\mathrm{IC}_{50}, \% ; \mathrm{ppm}$ & References \\
\hline Aloysia gratissima & HSV-1 & $65 \mathrm{ppm}$ & [59] \\
\hline Artemisia arborescens & HSV-1/HSV-2 & $2.4 / 4.1 \mu \mathrm{g} / \mathrm{ml}$ & [60] \\
\hline Artemisia douglasiana & HSV-1 & $83 \mathrm{ppm}$ & [59] \\
\hline Cinnamonum verum & HSV-1 & $0.008 \%$ & [61] \\
\hline Citrus limon & HSV-1 & $0.0015 \%$ & [62] \\
\hline Cymbopogon citratus & HSV-1 & $0.1 \%$ & [63] \\
\hline Eucalyptus globulus & HSV-1/HSV-2 & $0.009 / 0.008 \%$ & [64] \\
\hline Eupatorium patens & HSV-1 & $125 \mathrm{ppm}$ & [59] \\
\hline Hyssopus officinalis & HSV-1/HSV-2 & $0.0001 / 0.0006 \%$ & {$[62,65]$} \\
\hline Illicium verum & HSV-1/HSV-2 & $0.004 / 0.003 \%$ & {$[62,66]$} \\
\hline Juniperus oxycedrus & HSV-1 & $0.02 \%$ & [67] \\
\hline Lavandula latifolia & HSV-1 & $1 \%$ & [63] \\
\hline Leptospermum scoparium & HSV-1/HSV-2 & $0.0001 / 0.00006 \%$ & [68] \\
\hline Matricaria recutita & HSV-1/HSV-2 & $0.00003 / 0.00015 \%$ & {$[62,66]$} \\
\hline Melaleuca alternifolia & HSV-1/HSV-2 & $0.0009 / 0.0008 \%$ & [64] \\
\hline Mentha piperita & HSV-1/HSV-2 & $0.002 / 0.0008 \%$ & [69] \\
\hline Origanum majorana & HSV-1 & $1 \%$ & [63] \\
\hline Pinus mugo & HSV-1/HSV-2 & $0.0007 \%$ & {$[62,66]$} \\
\hline Rosmarinus officinalis & HSV-1 & $1 \%$ & [63] \\
\hline Santalum album & HSV-1/HSV-2 & $0.0002 / 0.0005 \%$ & {$[62,65]$} \\
\hline Santolina insularis & HSV-1/HSV-2 & $0.0001 \%$ & [70] \\
\hline Tessaria absinthioides & HSV-1 & $105 \mathrm{ppm}$ & [59] \\
\hline Thymus vulgaris & HSV-1/HSV-2 & $0.001 / 0.0007 \%$ & {$[62,65]$} \\
\hline Zingiber officinale & HSV-1/HSV-2 & $0.0002 / 0.0001 \%$ & {$[62,65]$} \\
\hline Artemisia douglasiana & DEN-2 & $60 \mathrm{ppm}$ & [59] \\
\hline Eupatorium patens & DEN-2 & $150 \mathrm{ppm}$ & [59] \\
\hline Origanum vulgare & NDV & $0.025 \%$ & [71] \\
\hline Laurus nobilis & SARS-CoV & $0.012 \%$ & [67] \\
\hline Lippia junelliana & Junin virus & $20 \mathrm{ppm}$ & [59] \\
\hline Lippia turbinata & Junin virus & $14 \mathrm{ppm}$ & [59] \\
\hline
\end{tabular}

$\mathrm{IC}_{50}=50 \%$ inhibitory concentration; $\mathrm{HSV}=$ herpes simplex virus (DNA virus); DEN = dengue virus (RNA virus); NDV = Newcastle disease virus (DNA virus); SARS = severe acute respiratory syndrome; SARS-CoV = SARS-associated coronarvirus (RNA virus); Junin virus (RNA virus). so that little or no viral progeny is produced. These antiviral drugs should act at low concentrations and should not influence the host cell machinery, prevent the spread of viruses, and ultimately cure infected cells. On the other hand, virucidal drugs denature viral structural proteins or glycoproteins, thus, infectivity of virus particles is completely lost. To learn more about the antiviral mechanism of essential oils on enveloped viruses, we investigated exemplarily the antiviral activity of anise (Pimpinella anisum) oil, hyssop (Hyssopus officinalis) oil, thyme (T. vulgaris) oil, dwarf-pine (Pinus mugo) oil, citrus (Citrus limon) oil, manuka (Leptospermum scoparium) oil, ginger (Zingiber officinale) oil, camomile (Matricaria recutita) oil, and sandalwood (Santalum album) oil against HSV-1 and HSV-2 in vitro. The replication cycle of herpes simplex virus is characterized by a complex sequence of different steps which offers opportunities to antiviral agents to intervene. In order to determine the mode of action, essential oils were added to host cells (African green monkey kidney cells) and viruses at different times during viral infection to identify the stage and target site at which infection might be inhibited,

(i) host cells (African green monkey kidney cells) were pretreated for $1 \mathrm{~h}$ with essential oils prior to inoculation with herpesviruses (pretreatment cells),

(ii) herpesviruses were incubated with essential oils for $1 \mathrm{~h}$ prior to infection of host cells (pretreatment viruses),

(iii) herpesviruses were mixed with essential oils and added to the host cells immediately (adsorption),

(iv) host cells were incubated with essential oils after penetration of herpesviruses into the cells (intracellular replication).

Inhibition of HSV replication was measured by a plaque reduction assay as described previously [64]. In this assay, the number of plaques (pfu; plaque forming units) of drug-treated viruses were expressed in percent of the untreated control (number of plaques formed by viruses in the absence of essential oil). In all assays the maximum noncytotoxic concentrations of the essential oils tested were used. 
Fig. 2. Effect of different essential oils on herpes simplex virus type 1 and type 2 infectivity after pretreatment of viruses for $1 \mathrm{~h}$ with maximum noncytotoxic concentrations of essential oils. Untreated controls were arbitrarily set to $100 \%$. Data represent remaining decreased viral infectivity compared to untreated herpesvirus. PFU = Plaque forming unit. Anis oil: Pimpinella anisum oil; hyssop oil: Hyssopus officinalis oil; thyme oil: Thymus vulgaris oil; dwarf pine oil: Pinus mugo oil; citrus oil: Citrus limon oil; manuka oil: Leptospermum scoparium oil; ginger oil: Zingiber officinale oil; camomile oil: Matricaria recutita oil; sandalwood oil: Santalum album oil.

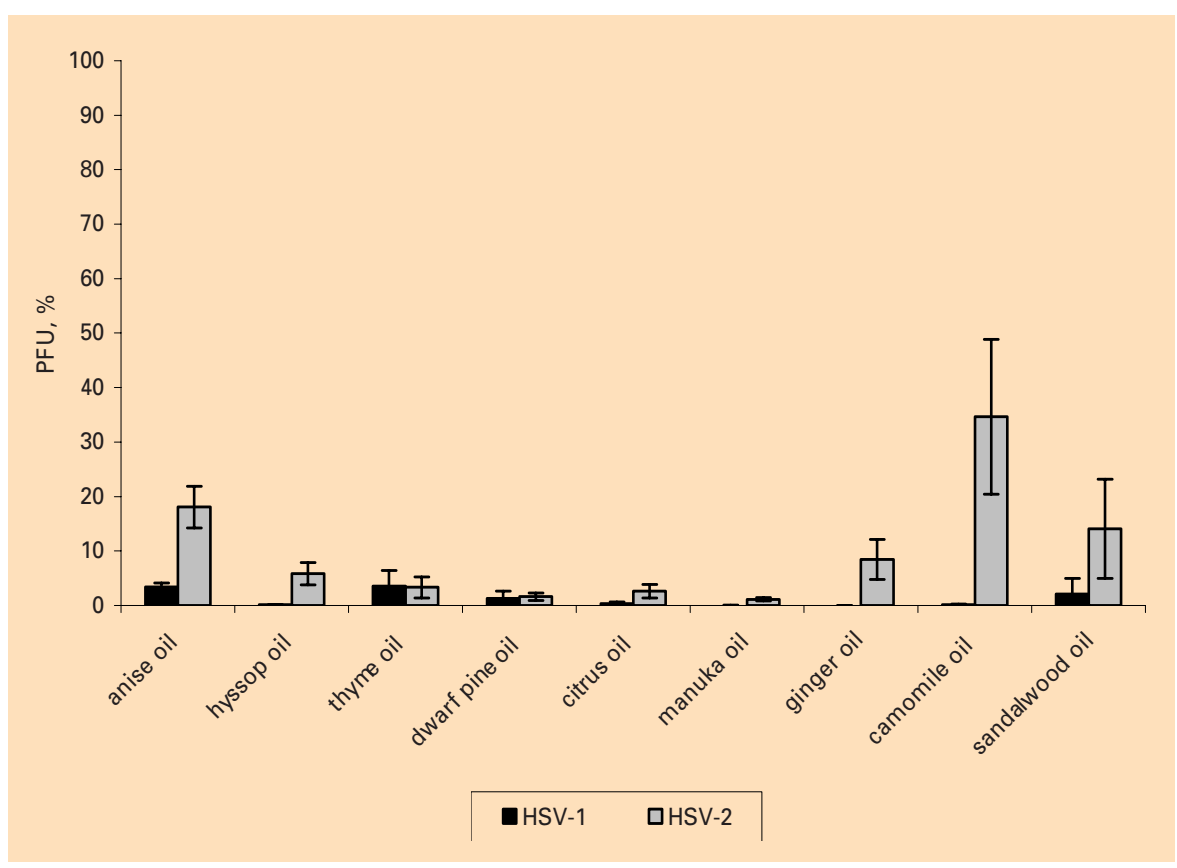

According to our findings, pretreatment of cells with essential oils for $1 \mathrm{~h}$ prior to virus infection did not reduce the virus plaque formation, indicating that essential oils did not affect the adsorption of viruses to cell surface, and did not interfere with virus binding by blocking cellular receptors. On the other hand, pretreatment of viruses with essential oils for $1 \mathrm{~h}$ prior to cell infection caused a significant reduction of plaques of 95-99\% for HSV-1 and of 70-98\% for HSV-2, respectively (fig. 2). Out of the oils tested, only dwarf-pine (P. mugo) oil and citrus ( $C$. limon) oil reduced plaque formation of about $80 \%$ for HSV-1 and HSV-2 when added during adsorption of virus to host cells $[62,65,68]$.

In contrast, when essential oils were added to the overlay medium after penetration of viruses into the host cells, only manuka (L. scoparium) oil significantly reduced plaque formation of HSV-1 of about $40 \%$. Only few reports demonstrated a virucidal activity of essential oils against herpesviruses. Saddi et al. [60] recently demonstrated the virucidal effect of Artemisia arborescens essential oil against HSV-1 and HSV-2.

In conclusion, our results indicate that in particular free viruses are very sensitive to essential oils. Both types of herpes simplex virus are affected before adsorption or during adsorption to cell surface but not after penetration into cells, the typical mode of action of nucleoside analogues like acyclovir. These findings suggest that essential oils interfere with the virus envelope or by masking viral components which are necessary for adsorption or entry into host cells. An electron microscopic examination demonstrated that the envelope of HSV-1 was disrupted when treated with oregano (O. vulgare) oil and clove (S. aromaticum) oil [71]. Furthermore, eugenol (4-hydroxy-3-methoxy-allyl-benzene), the main component of clove oil, was shown to be a very effective agent against
HSV-1 and HSV-2 in vitro [72]. All these findings are in accordance with the data of investigations on the antiviral activity of essential oils against enveloped DNA and RNA viruses mentioned above.

\section{Clinical Trials}

A randomized, placebo-controlled, investigator-blinded protocol was used to evaluate the efficacy of tea tree essential oil ( $6 \%$ TTO gel) in the treatment of recurrent herpes labialis [73]. The median time to re-epithelization after treatment with this essential oil was 9 days compared to 12.5 days after placebo, indicating some benefit from essential oil treatment. TTO might be a potentially useful, cheaper alternative for other topical therapies, which poses little threat of inducing resistance to antiviral agents. Besides essential oils, many other herbal preparations with antiviral activity were identified, clinical trials have been performed, and most of them described benefits for the treated patients [74]. There remains a need for larger, stringently designed, randomized clinical trials with essential oils to provide conclusive evidence of their efficacy.

\section{Summary}

In summary, there is considerable evidence emerging from in vitro studies and controlled clinical trials of the potential of plant-derived substances as leads for the development of antiviral drugs against viral infections. In particular, the antiviral properties of essential oils from several plant extracts, responsible for their characteristic odor, have been described in recent years. Various viruses, including the human pathogen herpes simplex virus, were found to be very susceptible to the inhibitory action of essential oils. These results support the potential use of essential oils in toto from medicinal plants 
Table 7. Cytotoxicity of essential oils in vitro

\begin{tabular}{|c|c|c|c|c|}
\hline Origin of essential oil & Cell line & Incubation time, $\mathrm{h}$ & $\mathrm{CC}_{50}, \mu \mathrm{g} / \mathrm{ml}$ & References \\
\hline \multirow{6}{*}{$\begin{array}{l}\text { Backhousia citriodora } \\
\text { (lemon myrtle) }\end{array}$} & F1-73 & 4 & 140 & [75] \\
\hline & dermal epithelial cells & 24 & 100 & \\
\hline & dermal fibroblasts & 4 & 120 & \\
\hline & & 24 & 70 & \\
\hline & HepG2 (liver carcinoma) & 4 & 80 & \\
\hline & & 24 & 40 & \\
\hline \multirow{4}{*}{$\begin{array}{l}\text { Commiphora molmol } \\
\text { (myrrh) }\end{array}$} & gingival fibroblasts & 24 & $\geq 25$ & {$[76]$} \\
\hline & & 48 & 5-10 & \\
\hline & gingival epithelial cells & 24 & $\geq 25$ & \\
\hline & & 48 & $5-10$ & \\
\hline \multirow{3}{*}{$\begin{array}{l}\text { Lavandula angustifolia } \\
\text { (lavender) }\end{array}$} & HMEC-1 (microvascular endothelial cells) & 1 & 1950 & {$[77]$} \\
\hline & HNDF & & & \\
\hline & 153BR (fibroblasts) & 1 & 1690 & \\
\hline \multirow[t]{8}{*}{ Lavandula stoechas } & KB (epidermoid carcinoma) & n.a. & $>20$ & [78] \\
\hline & KB-V (drug resistant $\mathrm{KB}$ ) & & $>20$ & \\
\hline & BC-1 (mamma carcinoma) & & $>20$ & \\
\hline & Lu-1 (lung carcinoma) & & $>20$ & \\
\hline & Col-2 (colon carcinoma) & & 9.8 & \\
\hline & LNCaP (prostate carcinoma) & & 17.6 & \\
\hline & P388 (murine leukemia) & & $>5$ & \\
\hline & 3T6 (fibroblasts) & & 286.8 & \\
\hline \multirow{3}{*}{$\begin{array}{l}\text { Syzygium aromaticum } \\
\text { (clove) }\end{array}$} & HMEC-1 (see above) & 1 & 180 & {$[79]$} \\
\hline & HNDF & 1 & 250 & \\
\hline & 153BR & 1 & 170 & \\
\hline \multirow[t]{6}{*}{ Melissa officinalis } & A549 (lung carcinoma) & 48 & $20-100$ & {$[81]$} \\
\hline & Caco-2 (colon carcinoma) & & & \\
\hline & MCF-7 (mamma carcinoma) & & & \\
\hline & HL-60 (leukemia) & & & \\
\hline & K562 (leukemia) & & & \\
\hline & B16F10 (murine) & & & \\
\hline \multirow[t]{2}{*}{ Melissa officinalis } & HaCaT (keratinocytes) & 48 & 15.3 & {$[30]$} \\
\hline & BEAS-2B (bronchial epithelial cells) & 48 & 10.6 & \\
\hline \multirow{2}{*}{$\begin{array}{l}\text { Nepeta cataria } \\
\text { (catnip) }\end{array}$} & HaCaT (keratinocytes) & 48 & 165.7 & \\
\hline & BEAS-2B (bronchial epithelial cells) & 48 & 161 & \\
\hline Santalum album & RC-37 (monkey kidney) & 96 & 15 & {$[62]$} \\
\hline Matricaria recutita & & & 30 & \\
\hline Leptospermum scoparium & & & 35 & \\
\hline Pinus mugo & & & 40 & \\
\hline Zingiber officinale & & & 40 & \\
\hline Citrus limon & & & 45 & \\
\hline Melaleuca alternifolia & $\mathrm{RC}-37$ & 96 & 60 & {$[64]$} \\
\hline Thymus vulgaris & $\mathrm{RC}-37$ & 96 & 70 & {$[62]$} \\
\hline Hyssopus officinalis & & & 75 & \\
\hline Mentha piperita & $\mathrm{RC}-37$ & 96 & 140 & [69] \\
\hline Illicium verum & $\mathrm{RC}-37$ & 96 & 160 & {$[62]$} \\
\hline Eucalyptus globulus & $\mathrm{RC}-37$ & 96 & 300 & {$[64]$} \\
\hline
\end{tabular}


as agents for the treatment of viral infections and suggests the application of this type of natural products as disinfectants or topical antiviral drugs.

\section{Cytotoxicity and Its Consequences on the Antibacterial and Antiviral Properties of Essential Oils}

\section{Cytotoxicity of Essential Oils in vitro}

The pharmaceutical market offers a wide range of drug products for topical application that contain essential oils. The use of essential oils as antimicrobial agents is not only limited by their effective concentrations in vitro but also by the concentrations that can be obtained at the site of action. These depend on the one hand on resorption and transport of the active constituents but on the other hand on the maximum dosage that can be administered without toxic side effects.

Regarding essential oils a number of investigations in cell culture systems have been carried out in order to predict their toxicity to mammalian cells in vivo (table 7). Most of the in vitro tests were carried out using human fibroblasts or dermal epithelial cells, but also tumor cell lines were used. Others use monkey kidney cells as they are also suitable for antiviral tests. Essential oils exert cytotoxic activity in vitro at $\mathrm{CC}_{50}$ values from $5.0-1,950 \mu \mathrm{g} / \mathrm{ml}$ depending on incubation time (1-96 h). In comparison, to achieve an antibacterial effect in vitro, essential oil concentrations of about $20-20,000 \mu \mathrm{g} / \mathrm{ml}$ are required. That means that essential oils may exert cytotoxic effects to tissue cells at concentrations which do not yet show an antibacterial effect. On the other hand, essential oils exhibit antiviral activity even at $\mathrm{IC}_{50}$ values of $1-200 \mu \mathrm{g} / \mathrm{ml}$.

The cytotoxic activity of essential oils is based on their individual components. As in bacterial cells, the cell membrane is one of the sites of action where essential oils and essential oil components were shown to cause permeabilization and depolarisation and to reduce the activity of membrane-associated enzymes [82]. In addition, an interaction with cellular metabolism $[82,83]$ and an induction of apoptosis have been demonstrated for essential oils and oil components [84-86].

\section{Implications for Therapeutic Use of Essential Oils}

In vitro cytotoxicity data may overestimate the toxicity of a substance in vivo, as neither tissue structures nor biotransformation and transport processes may be simulated in cell culture. Most cell culture models use a cell monolayer which is brought in direct contact with the test substance in culture medium and incubated for up to $96 \mathrm{~h}$ - these test conditions display the 'worst case', which is unlikely to occur in vivo. Correlations of in vitro and in vivo toxicity data have been carried out in order to develop models that allow a prediction of systemic toxicity in vivo from cell culture data. One example is the system of Halle and Göres [87] (table 8).

According to this classification, the expected systemic toxicity of most essential oils can be rated as moderate to low. Clinical studies about the topical use of essential oils (e.g. TTO, eucalyptus oil, and pine (Pinus sylvestris) needle oil) demonstrate that they are tolerated well both when used inhalatively or when applied to the skin in topical formulation. Adverse effects that were reported are local irritation on skin and mucous membranes as well as allergic reactions including contact dermatitis [35-37, 88, 89]. However, the ingestion of a few milliliters of essential oils may cause severe symptoms of intoxication like vomiting, respirational failure, and unconsciousness and may lead to death especially when infants are concerned [89]. From in vitro cytotoxicity data and the reports about toxicity and irritation potential in vivo, it is recommended strictly not to exceed the maximum daily dosage, when administered orally. In addition, the undiluted oils or preparations with high concentrations of essential oils should not be applied to mucous membranes or damaged skin. For inhalational use, the oils should be dosed in a way that they are barely detectable by odor as for many oils these concentrations were shown to facilitate secretolysis in an animal model most effectively in comparison to higher doses [90]. In addition, it was shown on ciliated nasal epithelium that low concentration of essential oil $(0.2 \%)$ stimulated the ciliary beat frequency more effectively than high concentrations (2\%) [91]. This is in accordance to the findings of Riechelmann and co-workers [92], who reported a decrease of ciliary beat frequency in human ciliated
Table 8. In vitro classification of cytotoxicity and prediction of in vivo toxicity of substances according to Halle and Göres [87]

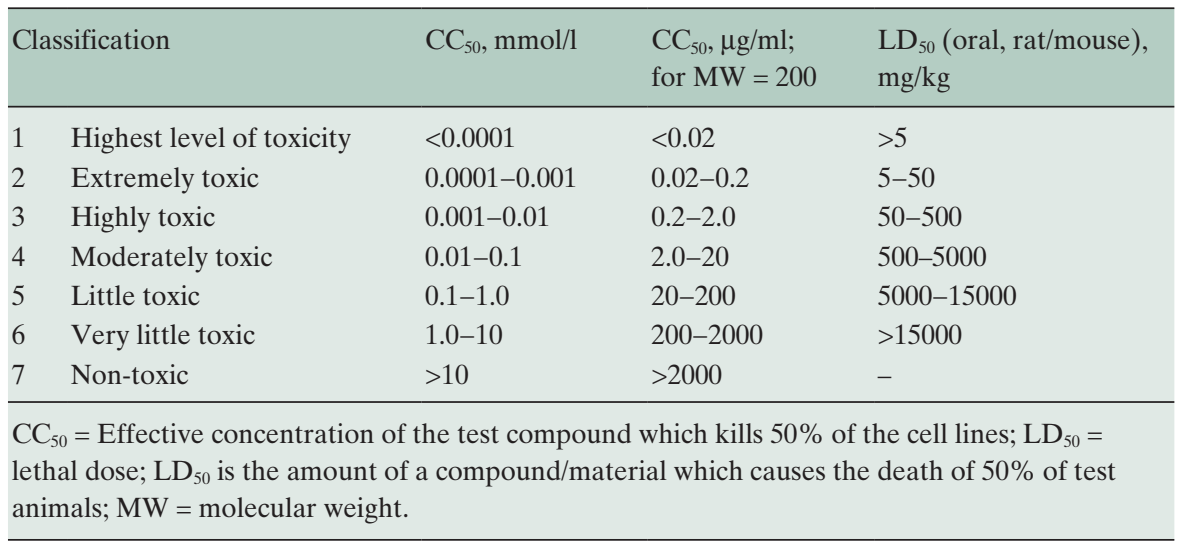


respiratory cells when exposed to air concentrations of more than $5 \mathrm{~g} / \mathrm{m}^{3}$ of menthol, eucalyptus oil, or pine needle oil.

In order to evaluate benefits and risks of application of essential oils, it has to be taken into account that they are not primarily used as antibacterial/antiviral agents. When used at concentrations below their MIC, they may as well exert rubefacient, local anaesthetic, spasmolytic, antiphlogistic, secretolytic, or secretomotoric effects, which altogether contribute to their therapeutic efficacy.

\section{Conflict of Interest}

The authors declared no conflict of interest.

\section{References}

1 Cantrell CL, Fischer NH, Urbatsch L, Guire MS, Franzblau SG: Antimycobacterial crude plant extracts from South, Central, and North America. Phytomedicine 1998;5:137-145.

2 Cowan MM: Plant products as antimicrobial agents. Clin Microbiol Rev 1999;12:564-582.

3 Reichling J: Plant-microbe interaction and secondary metabolites with antiviral, antibacterial and antifungal properties; in Wink M (ed): Functions of Plant Secondary Metabolites and Their Exploitation in Biotechnology. Sheffield, Sheffield Academic Press, 1999, pp 187-273.

4 Pyun MS, Shin S: Antifungal effects of the volatile oils from Allium plants against Trichophyton species and synergism of the oils with ketoconazole. Phytomedicine 2006;13:394-400.

5 Setzer WN, Vogler B, Schmidt JM, Leahy JG, Rives R: Antimicrobial activity of Artemisia douglasiana leaf essential oil. Fitoterapia 2004;75:192-200.

6 Saeed MA, Sabir AW: Antibacterial activities of some constituents from oleo-gum-resin of Commiphora mukul. Fitoterapia 2004;75:204-208.

7 Cheng SS, Lin HY, Chang ST: Chemical composition and antifungal activity of essential oils from different tissue of Japanese Cedar (Cryptomeria japonica). J Agric Food Chem 2005;53:614-619.

8 Hammer KA, Carson CF, Riley TV: Antimicrobial activity of essential oils and other plant extracts. J Appl Microbiol 1999;86:985-990.

9 D'Auria FD, Tecca M, Strippoli V, Salvatore G, Battinelli L, Mazzanti G: Antifungal activity of Lavandula angustifolia essential oil against Candida albicans yeast and mycelial form. Med Mycol 2005;43: 391-396.

10 Oliva B, Piccirilli E, Ceddia T, Pontier E, Aureli P, Ferrini AM: Antimycotic activity of Melaleuca alternifolia essential oil and its major components. Lett Appl Micobiol 2003;37:185-187.

11 Imai H, Osawa K, Yasuda H, Hamashima H, Arai $\mathrm{T}$, Sasatsu M: Inhibition by essential oils of pepermint and spearmint of the growth of pathogenic bacteria. Microbios 2001;106:31-39.

12 El-Kamali HH, Ahmed AH, Mohammed AS, Yahia AA, El-Tayeb IH, Ali AA: Antibacterial properties of essential oils from Nigella sativa, Cymbopogon citratus leaves, and Pulicaria undulata aerial parts. Fitoterapia 1998;69:77-78.

13 Vila R, Valenzuela L, Bello H, Canigueral S, Montes M, Adzet T: Composition and antimicrobial activity of the essential oil of Peumus boldus leaves. Planta Med 1999;65:178-179.

14 Kosalec I, Pepeljnjak S, Kustrak D: Antifungal activity of fluid extract and essential oil from anise fruits (Pimpinella anisum L., Apiaceae). Acta Pharm 2005;55:377-385.

15 Pitarokili D, Couladis M, Petsikos-Panayotarou N, Tzakou O: Composition and antifungal activity on soil-borne pathogens of the essential oil of Salvia sclarea from Greece. J Agric Food Chem 2002;50: 6688-6691.
16 Romagnoli C, Bruni R, Andreotti E, Rai MK, Vicentini CB, Mares D: Chemical characterization and antifungal activity of essential oil of capitula from wild India Tagetes patula L. Protoplasma 2005; 225:57-65.

17 Salgueiro LR, Pinto E, Goncalves MJ, Pina-Vaz C, Cavaleiro C, Rodrigues AG, Palmeira A, Costa-deOliveira S, Martinez-de-Oliveira J: Chemical composition and antifungal activity of the essential oil of Thymbra capitata. Planta Med 2004;70:572-575.

18 Pinto E, Pina-Vaz C, Salgueiro L, Goncalves MJ, Costa-de-Oliveira S, Cavaleiro C, Palmeira A, Rodrigues A, Martinez-de-Oliveira J: Antifungal activity of the essential oil of Thymus pulegioides on Candida, Aspergillus and dermatophyte species. J Med Microbiol 2006;55:1367-1373.

19 Sonboli A, Mirjalili MH, Hadian J, Ebrahimi SN, Yousefzadi M: Antibacterial activity and composition of the essential oil of Ziziphora clinopodioides subsp. bungeana (Juz.) Rech. f. from Iran. Z Naturforsch [C] 2006;61:677-680.

20 Bergonzelli GE, Donnicola D, Porta N, CorthesyTheulaz IE: Essential oils as components of a dietbased approach to management of Helicobacter infection. Antimicrob Agents Chemother 2003;47: 3240-3246.

21 Weseler A, Geiss HK, Saller R, Reichling J: A novel colorimetric broth microdilution method to determine the minimum inhibitor concentration (MIC) of antibiotics and essential oils against Helicobacter pylori. Pharmazie 2005;60:497-502.

22 Kalpoutzaki E, Aligiannis N, Mentis A, Mitaku S, Charvala C: Composition of the essential oil of two Nepeta species and in vitro evaluation of their activity against Helicobacter pylori. Planta Med 2001; 67:880-883.

23 Ohno T, Kita M, Yamaoka Y, Imamura S, Yamamoto T, Mitsufuji S, Kodama T, Kashima K, Imanishi J: Antimicrobial activity of essential oils against Helicobacter pylori. Helicobacter 2003;8:207-215.

24 Tzakou O, Skaltsa H: Composition and antibacterial activity of the essential oil Satureja parnassica subsp. parnassica. Planta Med 2003;69:282-284.

25 Harkenthal M, Layh-Schmitt G, Reichling J: Effect of Australian tea tree oil on the viability of the wall-less bacterium Mycoplasma pneumoniae. Pharmazie 2000;55:380-384.

26 Furneri PM, Paolino D, Saija A, Marino A, Bisignano G: In vitro antimycoplasmal activity of Melaleuca alternifolia essential oil. J Antimicrob Chemother 2006;58:706-707.

27 Inouye S, Yamaguchi H, Takizawa T: Screening of the antibacterial effects of a variety of essential oils on respiratory tract pathogens using a modified dilution assay method. J Infect Chemother 2001;7: 251-254.

28 Inouye S, Takizawa T, Yamaguchi H: Antibacterial activity of essential oils and their major constituents against respiratory tract pathogens by gaseous contact. J Antimicrob Chemother 2001:47:565-573.
29 Fabio A, Cermelli C, Fabio G, Nicoletti P, Quaglio P: Screening of the antibacterial effects of a variety of essential oils on microorganisms responsible for respiratory infections. Phytother Res 2007;21:374-377.

30 Suschke U, Sporer F, Schneele J, Schnitzler P, Geiss HK, Reichling J: Antibacterial and cytotoxic activity of Nepeta cataria L., Nepeta cataria var. citriodora (BECK.) BALB. and Melissa officinalis L. essential oils. Nat Prod Commun 2007;2:1-10.

31 Suschke U: Untersuchungen zur pharmazeutischen Qualität sowie zur antimikrobiellen und cytotoxischen Aktivität der ätherischen Öle von Nepeto cataria L., Nepeta cataria var. citriodora (BECK.) BALB. und Melissa officinalis L. Dissertation, Universität Heidelberg, 2007.

32 Reichling J, Suschke U, Schneele J, Geiss HK: Antibacterial activity and irritation potential of selected essential oil components - structure-activity relationship. Nat Prod Commun 2006;1:1003-1012.

33 Horne D, Holm M, Oberg DG, Chao S, Young DG: Antimicrobial effects of essential oils on Staphylococcus pneumoniae. J Essential Oil Res 2001;13: 387-392.

34 Hammer KA, Carson CF, Riley TV: Antifungal effects of Melaleuca alternifolia (tea tree) oil and its components on Candida albicans, Candida glabrata and Saccharomyces cerevisiae. J Antimicrob Chemother 2004;12:1-5.

35 Carson CF, Hammer KA, Riley TV: Melaleuca alternifolia (tea tree) oil: a review of antimicrobial and other medicinal properties. Clin Microbiol Rev 2006;19:50-62.

36 Caelli M, Porteous J, Carson C, Heller R, Riley T: Tea tree oil as an alternative topical decolonization agent for methicillin-resistant Staphylococcus aureus. J Hosp Infect 2000;46:236-237.

37 Dryden M, Dailly S, Crouch M: A randomized, controlled trial of tea tree oil topical preparations versus a standard topical regimen for the clearance of MRSA infection. J Hosp Infect 2004;56:283-286.

38 Reichling J, Harkenthal M, Geiss HK, HoppeTichy T, Saller R: Electron microscopic and biochemical investigations on the antibacterial effects of Australian tea tree oil against Staphyloccocus aureus. Curr Top Phytochem 2002;5:77-84.

39 LorianV, Gemmel CG: Effects of Low Antibiotic Concentrations on Bacteria: Effects on Ultrastructure, Virulence, and Susceptibility to Immunodefenses. Baltimore, Williams and Wilkins, 1980, pp 493.

40 Cox SD, Gustafson JE, Mann CM, Markham JL, Liew YC, Hartland RP, Bell HC, Warmington JR, Wyllie SG: Tea tree oil causes $\mathrm{K}^{+}$leakage and inhibits respiration in Escherichia coli. Lett Appl Microbiol 1998;26:355-358.

41 Cox SD, Mann CM, Markham JL, Bell HC, Gustafson JE, Warmington JR, Wyllie SG: The mode of antimicrobial action of the essential oil of Melaleuca alternifolia (tea tree oil). J Appl Microbiol 2000;88:170-175. 
42 Takaisi-Kikuni NB, Kriiger D, Gnann W, Wecke J: Microcalorimetric and electron microscopic investigation on the effects of essential oil from Cymbopogon densiflorus on Staphylococcus aureus. Microbios 1996;88:55-62.

43 Sikkema J, de Bont JAM, Poolman B: Interaction of cyclic hydrocarbons with biological membranes. J Biol Chem 1994;269:8022-8028.

44 Pattnaik S, Subramanyam VR, Rath CC: Effect of essential oils on the viability and morphology of Escherichia coli (SP-11). Microbios 1995;84:195-199.

45 Knobloch K, Weigand H, Weis N, Schwarm HM, Vigenschow H: Action of terpenoids on energy metabolism; in Brunke EJ (ed): Progress in Essential Oil Research. Berlin, Walter de Gruyter, 1986, pp 429-445.

46 Inoue Y, Shiraishi A, Hada T, Hirose K, Hamashima H, Shimada J: The antibacterial effects of terpene alcohols on Staphylococcus aureus and their mode of action. FEMS Microbiol Lett 2004;237: 325-331.

47 Shepira R, Mimran E: Isolation and characterization of Escherichia coli mutants exhibiting altered response to thymol. Microb Drug Resist 2007;13: 157-165.

48 Helander IM, Alakomi HL, Lavata-Kala K, Mattila-Sandholm T, Pol I, Smid EJ, Gorris LGM, von Wright A: Characterization of the action of selected essential oil components on Gram-negative bacteria. J Agric Food Chem 1998;46:3590-3595.

49 Oussalah M, Caillet S, Lacroix M: Mechanism of action of Spanish oregano, Chinese cinnamon, and savory essential oils against cell membranes and walls of Escherichia coli and Listeria monocy togenes. J Food Prot 2006;69:1046-1055.

50 Carson CF, Mee BJ, Riley TV: Mechanism of action of Melaleuca alternifolia (tea tree) oil on Staphylococcus aureus determined by time-kill, lysis, leakage, and salt tolerance assays and electron microscopy. Antimicrob Agents Chemother 2002;46: 1914-1920.

51 Gustafson JE, Liew YC, Chew S, Markham J, Bel HC, Wyllie SG, Warmington JR: Effects of tea tree oil on Escherichia coli. Lett Appl Microbiol 1998:26:194-198.

52 Ogunlana EA, Höglund G, Onawunmi G, Sköld O: Effects of lemongrass oil on the morphological characteristics and peptidoglycan synthesis of Escherichia coli. Microbios 1987;50:43-49.

53 Rhayour K, Bouchikhi T, Tantaoui-Elaraki A, Sendide K, Remmal A: The mechanism of bactericidal action of oregano and clove essential oils and of their phenolic major components on Escherichia coli and Bacillus subtilis. J Essential Oil Res 2003;15:356-362.

54 Schelz Z, Molnar J, Hohmann J: Antimicrobial and antiplasmid activities of essential oils. Fitoterapia 2006;77:279-285.

55 Jassim SA, Naji MA: Novel antiviral agents: a medicinal plant perspective. J Appl Microbiol 2003;95: 412-427.

56 Bacon TH, Levin MJ, Leary JJ, Sarisky RT, Sutton D: Herpes simplex virus resistance to acyclovir and penciclovir after two decades of antiviral therapy. Clin Microbiol Rev 2003;16:114-128.

57 Morfin F, Thouvenot D: Herpes simplex virus resistance to antiviral drugs. J Clin Virol 2003;26:29_ 37.

58 Schnitzler P, Koch C, Reichling J: Susceptibility of drug-resistant clinical herpes simplex virus type 1 strains of essential oils of ginger, thyme, hyssop, and sandalwood. Antimicrob Agents Chemother 2007;51:1859-1862.
59 Garcia CC, Talarico L, Almeida N, Colombres S, Duschatzky C, Damonte EB: Virucidal activity of essential oils from aromatic plants of San Luis, $A r$ gentina. Phytother Res 2003;17:1073-1075.

60 Saddi M, Sanna A, Cottiglia F, Chisu L, Casu L, Bonsignore L, De Logu A: Antiherpes activity of Artemisia arborescens essential oil and inhibition of lateral diffusion in Vero cells. Ann Clin Microbiol Antimicrob 2007;6:1-10.

61 Bourne KZ, Bourne N, Reising SF, Stanberry LR: Plant products as topical microbicide candidates: assessment of in vitro and in vivo activity against herpes simplex type 2. Antiviral Res 1999;42:219226.

62 Koch C: Antivirale Effekte ausgewählter ätherischer Öle auf behüllte Viren unter besonderer Berücksichtigung des Herpes simplex Virus Typ 1 und 2. Dissertation, Universität Heidelberg, 2005.

63 Minami M, Kita M, Nakaya T, Yamamoto T, Kuriyama H, Imanishi J: The inhibitory effect of essential oils on herpes simplex virus type 1 replication in vitro. Microbiol Immunol 2003;47:681-684.

64 Schnitzler P, Schön K, Reichling J: Antiviral activity of Australian tea tree oil and eucalyptus oil against herpes simplex virus in cell culture. Pharmazie 2001;56:343-347.

65 Koch C, Reichling J, Schneele J, Schnitzler P: Inhibitory effect of essential oils against herpes simplex virus type 2. Phytomedicine 2008;15:71-78.

66 Koch C, Reichling J, Schnitzler P: Essential oils inhibit the replication of herpes simplex virus type 1 (HSV-1) and type 2 (HSV-2); in Preedy VR, Watson RR (eds): Botanical Medicine in Clinical Practice. Wallingsford, CABI, 2008, pp 192-197.

67 Loizzo MR, Saab AM, Tundis R, Statti GA, Menichini F, Lampronti I, Gambari R, Cinatl J, Doerr HW: Phytochemical analysis and in vitro antiviral activities of the essential oils of seven Lebanon species. Chem Biodivers 2008;5:461-470.

68 Reichling J, Koch C, Stahl-Biskup E, Sojka C, Schnitzler P: Virucidal activity of a beta-triketone-rich essential oil of Leptospermum scoparium (manuka oil) against HSV-1 and HSV-2 in cell culture. Planta Med 2005;71:1123-1127.

69 Schuhmacher A, Reichling J, Schnitzler P: Virucidal effect of peppermint oil on the enveloped viruses herpes simplex virus type 1 and type 2 in vitro. Phytomedicine 2003;10:504-510.

70 De Logu A, Loy G, Pellerano ML, Bonsignore L, Schivo ML: Inactivation of HSV-1 and HSV-2 and prevention of cell-to-cell virus spread by Santolina insularis essential oil. Antiviral Res 2000;48:177185.

71 Siddiqui YM, Ettayebi M, Haddad AM, Al-Ahdal MN: Effect of essential oils on the enveloped viruses: antiviral activity of oregano and clove oils on herpes simplex virus type 1 and Newcastle disease virus. Med Sci Res 1996;24:185-186.

72 Tragoolpua Y, Jatisatieur A: Anti-herpes simplex virus activities of Eugenia caryophyllus (Spreng.) Bullock and S. G. Harrison and essential oil, eugenol. Phytother Res 2007;21:1153-1158.

73 Carson CF, Ashton L, Dry L, Smith DW, Riley TV: Melaleuca alternifolia (tea tree) oil gel (6\%) for the treatment of current herpes labialis. J Antimicrob Chemother 2001;48:450-451.

74 Martin KW, Ernst E: Antiviral agents from plants and herbs: a systematic review. Antivir Ther 2003;8: $77-90$.

75 Hayes AJ, Markovic B: Toxicity of Australian essential oil Backhousia citriodora (Lemon myrtle). Part 1 . Antimicrobial activity and in vitro cytotoxicity. Food Chem Toxicol 2002;40:535-543.
76 Tipton DA, Lyle B, Babich H, Dabbous MK: In vitro cytotoxic and anti-inflammatory effects of myrrh oil on human gingival fibroblasts and epithelial cells. Toxicol In Vitro 2003;17:301-310.

77 Prashar A, Locke IC, Evans CS: Cytotoxicity of lavender oil and its major components to human skin cells. Cell Prolif 2004:37:221-229.

78 Gören AC, Topcu G, Bilsel G, Bilsel M: The chemical constituents and biological activity of essential oil of Lavandula stoechas ssp. stoechas. Z Naturforsch [C] 2002;57:797-800.

79 Prashar A, Locke IC, Evans CS: Cytotoxicity of clove (Syzygium aromaticum) oil and its major components to human skin cells. Cell Prolif 2006; 39:241-248.

80 Allahverdiyev A, Duran N, Ozguven M, Koltas S: Antiviral activity of the volatile oils of Melissa officinalis L. against Herpes simplex virus type-2. Phytomedicine 2004;11:657-661.

81 Carvalho de Sousa A, Sales Alviano D, Fitzgerald Blank A, Barreto Alves P, Sales Alviano C, Rocha Gattass C: Melissa officinalis L. essential oil: antitumoral and antioxidant activities. J Pharm Pharmacol 2004;56:677-681.

82 Carnesecchi S, Schneider Y, Ceraline J, Duranton B, Gosse F, Seiler N, Raul F: Geraniol, a component of plant essential oils, inhibits growth and polyamine biosynthesis in human colon cancer cells. J Pharmacol Exp Ther 2001;298:197-200.

83 Yu SG, Hildebrandt LA, Elson CE: Geraniol, an inhibitor of mevalonate biosynthesis, suppresses the growth of hepatomas and melanomas transplanted to rats and mice. J Nutr 1995;125:2763-2767.

84 Cavalieri E, Mariotto S, Fabrizi C, Carcereri de Prati A, Gottardo R, Leone, S, Berra V, Lauro GM, Ciampa AR, Suzuki H: $\alpha$-Bisabolol, a nontoxic natural compound, strongly induces apoptosis in glioma cells. Biochem Biophys Res Commun 2004;315:589-594.

85 Dudai N, Weinstein Y, Krup M, Rabinski T, Ofir $\mathrm{R}$ : Citral is a new inducer of caspase- 3 in tumor cell lines. Planta Med 2005;71:482-484.

86 Kumar A, Malik F, Bhushan S, Sethi VK, Shahi AK, Kaur J, Taneja SC, Qazi GN, Singh J: An essential oil and its major constituent isointermedeol induce apoptosis by increased expression of mitochondrial cytochrome $\mathrm{c}$ and apical death receptors in human leukaemia HL-60 cells. Chem Biol Interact 2008;171:332-47.

87 Halle W, Göres E: Prediction of $\mathrm{LD}_{50}$ values by cell culture. Pharmazie 1987;42:245-248.

88 Willms RU, Funk P, Walther C: Local tolerability of two preparations with eucalyptus oil and pineneedle oil. MMW Fortschr Med 2005;147(suppl 3):109-112.

89 Woolf A: Essential oil poisoning. J Toxicol Clin Toxicol 1999;37:721-727.

90 Boyd E, Sheppard E: The effect of steam inhalation of volatile oils on the output and composition of respiratory tract fluid. J Pharmacol Exp Ther 1968; 163:250-256.

91 Neher A, Gstöttner M, Thaurer M, Augustijns P, Reinelt M, Schobersberger W: Influence of essential and fatty oils on ciliary beat frequency of human nasal epithelial cells. Am J Rhinol 2008;22:130-134.

92 Riechelmann H, Brommer C, Hinni M, Maartin C: Response of human ciliated respiratory cells to a mixture of menthol, eucalyptus oil and pine needle oil. Arzneimittelforschung 1997;47:1035-1039. 